Article

\title{
Newly Synthesized Doxorubicin Complexes with Selected Metals-Synthesis, Structure and Anti-Breast Cancer Activity
}

\author{
Agata Jabłońska-Trypuć 1,* (D), Grzegorz Świderski ${ }^{2}$, Rafał Krętowski ${ }^{3}$ \\ and Włodzimierz Lewandowski ${ }^{2}$ \\ 1 Division of Sanitary Biology and Biotechnology, Faculty of Civil Engineering and Environmental \\ Engineering, Białystok University of Technology, Wiejska 45E Street, Białystok 15-351, Poland \\ 2 Division of Chemistry, Bialystok University of Technology, Białystok 15-351, Poland; \\ g.swiderski@pb.edu.pl (G.Ś.); w.lewandowski@pb.edu.pl (W.L.) \\ 3 Department of Pharmaceutical Biochemistry, Medical University of Białystok, Białystok 15-222, Poland; \\ r.kretowski@umb.edu.pl \\ * Correspondence: a.jablonska@pb.edu.pl; Tel.: +48-797-995-971; Fax: +48-85-746-9015
}

Received: 17 May 2017; Accepted: 1 July 2017; Published: 4 July 2017

\begin{abstract}
Doxorubicin (DOX) is very effective chemotherapeutic agent, however it has several major drawbacks. Therefore the motivation for developing novel drug complexes as anticancer agents with different mechanism of action has arisen. The aim of the present study was to evaluate the influence of newly synthesized DOX complexes with selected metals ( $\mathrm{Mg}, \mathrm{Mn}, \mathrm{Co}, \mathrm{Ni}, \mathrm{Fe}, \mathrm{Cu}, \mathrm{Zn}$ ) on apoptosis, cell cycle, viability, proliferation and cytotoxicity in the breast cancer cell line MCF-7. Complexation of DOX with metals has likewise been the subject of our research. The current work showed that the tested bivalent metals at a given $\mathrm{pH}$ condition formed metal:DOX complexes in a ratio of 2:1, while iron complexes with DOX in a ratio of 3:1. The studies also showed that selected metal-DOX complexes (Mg-DOX, Mn-DOX, Ni-DOX) at $0.5 \mu \mathrm{M}$ concentration significantly decreased cell viability and proliferation, however they increased caspase 7 activity. Results also indicated that studied metal-DOX complexes showed high cytotoxicity in MCF-7 cells. Therefore they were chosen for cell cycle check-points and apoptosis/necrosis analysis studied by flow cytometry. Obtained results suggest that doxorubicin complexed by specified metals can be considered as a potential anti-breast cancer agent, which is characterized by a higher efficacy than a parent drug.
\end{abstract}

Keywords: doxorubicin; metals; breast cancer; MCF-7

\section{Introduction}

The most commonly diagnosed cancers worldwide are lung cancer, breast cancer and colorectal cancer, however, in women, breast cancer is the most common malignant tumor. This is the most frequently occurring cancer among women especially in developed countries. Every year in the UK it is diagnosed in over 44,000 women and the incidence has increased over the past 20 years by 50 percent [1].

Breast cancer is characterized by following features: frequent aggressive invasion, early metastasis and resistance to multiple drugs used in therapy. All the above mentioned factors suggest the need for theexploration of the novel, more efficient anticancer agents without disruptive side effects. Doxorubicin (DOX) belongs to the anthracycline group - a class of drugs that are commonly used for breast cancer chemotherapy, often in conjunction with other compounds [2]. In the chemical structure of anthracyclines two parts can be distinguished: the aglycone, that consists of four rings two of which are aromatic rings (B and D), and the saccharide moiety (Figure 1). Rings indicated by symbols A, B, C 
and D differ from each other. Ring B with the hydroquinone structure differs from the $\mathrm{C}$ ring, which is devoid of hydroxyl groups. The side chain is located at the C-9 position of the A ring. It is linked to the carbonyl group and at the C-7 position of the amino sugar (daunosamine) and it is attached by a glycosidic linkage. Ring $\mathrm{D}$ has in turn a methoxyl group in the C-4 position. In the anthracycline antibiotic molecule several asymmetric carbon atoms can be distinguished: two of them in the aglycone (C-7 and C-9) and four in the sugar moiety (C-1, C-3, C-4, C-5). The presence of a carboxyl group (ring A), hydroxyl group (ring B) and the sugar moiety affect the interactions of the macromolecules within cells [3].

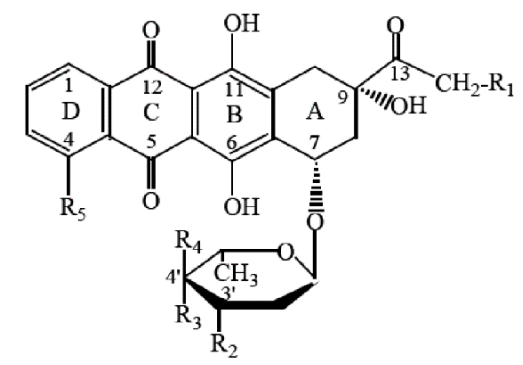

\begin{tabular}{|c|c|c|c|c|c|}
\hline & $\mathrm{R}_{1}$ & $\mathrm{R}_{2}$ & $\mathrm{R}_{3}$ & $\mathrm{R}_{4}$ & $\mathrm{R}_{5}$ \\
\hline daunorubicin & $\mathrm{H}$ & $\mathrm{NH}_{2}$ & $\mathrm{OH}$ & $\mathrm{H}$ & $\mathrm{OCH}_{3}$ \\
\hline idarubicin & $\mathrm{H}$ & $\mathrm{NH}_{2}$ & $\mathrm{OH}$ & $\mathrm{H}$ & $\mathrm{H}$ \\
\hline doxorubicin & $\mathrm{OH}$ & $\mathrm{NH}_{2}$ & $\mathrm{OH}$ & $\mathrm{H}$ & $\mathrm{OCH}_{3}$ \\
\hline epidoxorubucin & $\mathrm{OH}$ & $\mathrm{NH}_{2}$ & $\mathrm{H}$ & $\mathrm{OH}$ & $\mathrm{OCH}_{3}$ \\
\hline pirarubicin & $\mathrm{OH}$ & $\mathrm{NH}_{2}$ & & $\mathrm{H}$ & $\mathrm{OCH}_{3}$ \\
& & & & & \\
& & & & & \\
& & & & & \\
\end{tabular}

Figure 1. Structural formula of the selected anthracyclines regarding the functional groups of the individual compounds.

The above described chemical structure is characteristic for the anthracycline antibiotics belonging to the class I, such as DOX, daunorubicin, epirubicin, idarubicin, pirarubicin [4]. Anthracyclines contain in their chemical structure a fragment of both hydrophilic and hydrophobic properties, which allows them to binding to the plasma proteins and cellular membranes. Due to their polar nature they dissolve in water and display both acidic and basic properties. These compounds have crystalline structures and are stable at room temperature [5].

They are known to have cytotoxic properties against tumor cells through three different mechanisms. The first one is the intercalation between strands of DNA/RNA molecules, which results in interference with DNA/RNA synthesis in rapidly dividing cells, such as breast cancer cells [6]. The second mechanism is the inhibition of topoisomerase II activity, which is based on the binding of the anthracycline with the DNA-topoisomerase complex. Anthracyclines, such as doxorubicin, belong to the group of topoisomerase II poisons and therefore they may immobilize topoisomerase II-DNA complexes. For this reason they cause an inhibition of the release of DNA breaks generated by the enzyme. According to the literature, "catalytic inhibitors" inhibit enzymes binding to DNA substrate or cause the closing of the topoisomerase II in the form of a bracelet that surrounds DNA at the post-religation step. However, only topoisomerase II poisons activity can produce DNA breaks [7]. The third mechanism by which selected compounds from the anthracycline group influence cancer cells metabolism is the creation of iron-mediated oxygen free radicals [8].

Literature data indicate that the pharmacological properties of anthracyclines are indirectly connected with the presence of metal ions and with the environment of the metal-antibiotic chelates $[9,10]$. The investigations associated with metals such as $\mathrm{Cu}$ (II), $\mathrm{Hg}$ (II), $\mathrm{Ag}$ (I), $\mathrm{Ni}$ (II) and $\mathrm{Mg}$ (II) binding to anthracyclines have shown that the metal has the possibility to bound both to aglycone ring and to 
the sugar moiety-daunosamine. Furthermore, a considerable limitation is the solubility of the drug. Close to the solubility ratio metal-anthracyclines complexes have the capacity to create dimers [11]. The complexation of the anthracyclines by the metal ions led to discovery of the new, less toxic anticancer agents. The structure of the complexes, the impact that they have on redox reactions and the characteristics of the selected metal binding is still under investigation [12-14]. The locations where the metal is bound to the anthracycline are aglycone inner rings depending on the metal nature, with the simultaneous consideration of the ligand spatial structure (Table 1).

Table 1. Possible points of metal attachment to the anthracycline [13,15-19].

\begin{tabular}{|c|c|}
\hline Metal Ion & Possible Points of Anthracycline Attachment \\
\hline $\mathrm{Fe}(\mathrm{II})$ & $\begin{array}{l}\text { Carbonyl group (at } C-12^{\prime} \text { ) } \\
\text { Phenolic group (at } C-11^{\prime} \text { ) }\end{array}$ \\
\hline $\mathrm{Cu}(\mathrm{II})$ & $\begin{array}{l}\text { Carbonyl group (at C-5 }) \\
\left.\text { Phenolic group (at } C-6^{\prime}\right) \\
\text { Carbonyl group (at } C-12^{\prime} \text { ) } \\
\text { Phenolic group (at } C-11^{\prime} \text { ) }\end{array}$ \\
\hline $\mathrm{Yb}(\mathrm{II})$ & $\begin{array}{l}\text { Carbonyl group (at } C-12^{\prime} \text { ) } \\
\text { Phenolic group (at } C-11^{\prime} \text { ) }\end{array}$ \\
\hline
\end{tabular}

Metal-DOX complexes, by the increase of the oxidative stress level, could potentially induce apoptosis. $\mathrm{Fe}^{3+}$-DOX complex bound up with DNA, is stable in aqueous solution and in addition it can be reduced to $\mathrm{Fe}^{2+}$ through the action of reducing agents such as NADPH dependent cytochrome $\mathrm{P}_{450}$ reductase, glutathione or cysteine. These reactions are accompanied by the creation of superoxide anion and the conversion of anthracycline quinone to semiquinone free radicals. During the Haber-Weiss reaction, which is catalyzed by iron ions, hydrogen peroxide and highly reactive hydroxyl radicals are produced. Semiquinone radicals have the ability to transform into a C7 aglycone radical, which is a potent alkylating agent. Reactive oxygen species created with the participation of anthracyclines, cause DNA damage and lead to the apoptosis [20,21].

Apoptosis is a kind of programmed cell death, that occurs in multicellular organisms and it is important for homeostasis, normal cells and tissues growth and development, but also for cancer treatment. Any changes in the process of apoptosis significantly influence cells and tissues metabolism, e.g., may cause an abnormal cell growth, uncontrolled cell divisions and generation of mutations. Consequently, the control and regulation of apoptosis is a main target for new anticancer therapies [22,23]. In mammalian cells exist at least two pathways, by which an apoptosis occurs: an extrinsic death-receptor dependent apoptosis and intrinsic mitochondrial dependent apoptosis. In both above mentioned pathways the induction of cell death is connected with selected caspases activation: initiator caspases (e.g., caspase-8 and -9) and effector caspases (e.g., caspase-3, -6, and -7).

The purpose of this study was to evaluate the influence of selected, newly synthesized metal-DOX complexes on breast cancer cells proliferation, viability, cytotoxicity and apoptosis. The molar ratio of created metal-DOX complexes was determined by spectrophotometric titration in buffer solution at $\mathrm{pH}$ $=7.00$. Next, FT-IR and FT-Raman spectra of doxorubicin and UV-Vis spectra of metal-doxorubicin complexes were taken. Because DOX and other anthracyclines cause severe side effects, a need to synthesize new, more efficient DOX complexes with selected metals arises.

The current work is a part of the project involving several different aspects. The first one is the evaluation of antitumor activity of metal complexes as compared to selected ligands. The second are relational studies regarding molecular structure and distribution of electrical charge and cytotoxic effects of studied compounds. The third aspect is the study of synergistic effects, in other words mutual reinforcement of antineoplastic action of metal and ligand (with proven cytotoxic activity). The influence of metals on the distribution of electronic charge (determining biological properties) of selected ligands has been described in our earlier articles [24-27]. 


\section{Results}

\subsection{IR and Raman Spectra of DOX}

In the infrared and Raman spectrum DOX is characterized by some characteristic bands. At $3423 \mathrm{~cm}^{-1}$ we observed a wide, strong band coming from the stretching vibration of the hydroxyl group $\mathrm{vH}-\mathrm{OH}$, which demonstrates that the substance was hydrated. This band can mask other bands in the 3500-2900 range that are visible in the Raman spectrum $\left(3364,3092 \mathrm{~cm}^{-1}\right)$. The Raman spectra (in the range of 3500-2850 $\mathrm{cm}^{-1}$ ) have intense bands derived from the C-H chain tension of the sugar ring. In the IR spectrum these vibrations are low in intensity. The oscillation of the aromatic ring occurs throughout the spectral range. C-H oscillations derived from aliphatic groups (e.g., methoxy groups). At a wavelength of about $1730 \mathrm{~cm}^{-1}$, a characteristic midrange band from the $\delta \mathrm{N}-\mathrm{H}$ bending oscillation of the amino group of the sugar ring appears in the IR and Raman spectra. In the IR and Raman spectra at a wavelength of about $1007 \mathrm{~cm}^{-1}$ a midrange intensity band is generated from the oscillation of the C-O-C glycosidic moiety (Figure 2, Table 2).

Table 2. Wavenumbers $\left(\mathrm{cm}^{-1}\right)$, intensities and assignments of bands occurring in the IR (KBr, ATR) and Raman spectra of DOX hydrochloride and IR spectra for Cu-DOX complex.

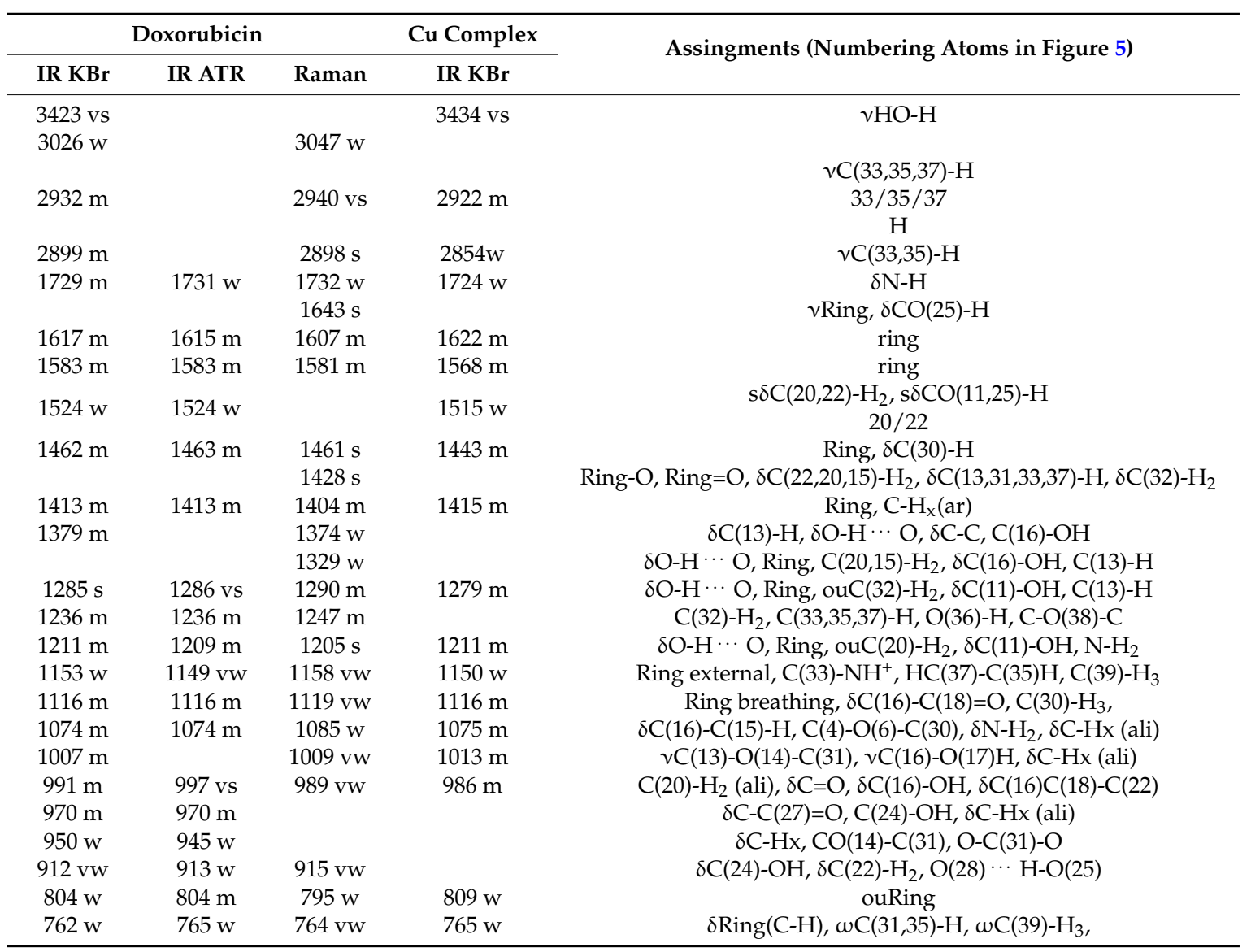

vs, s, w, vw, m. ou, ali and aro represent very strong, strong, weak, very weak, medium high band intensity, out-of-plane vibration, aliphatic and aromatic group; $v, \delta, \omega$ belong to the stretching, bending, and wagging vibration; $\mathrm{C}_{\mathrm{x}}-\mathrm{H}_{\mathrm{y}}$ represents xth carbon with y number of hydrogen. 


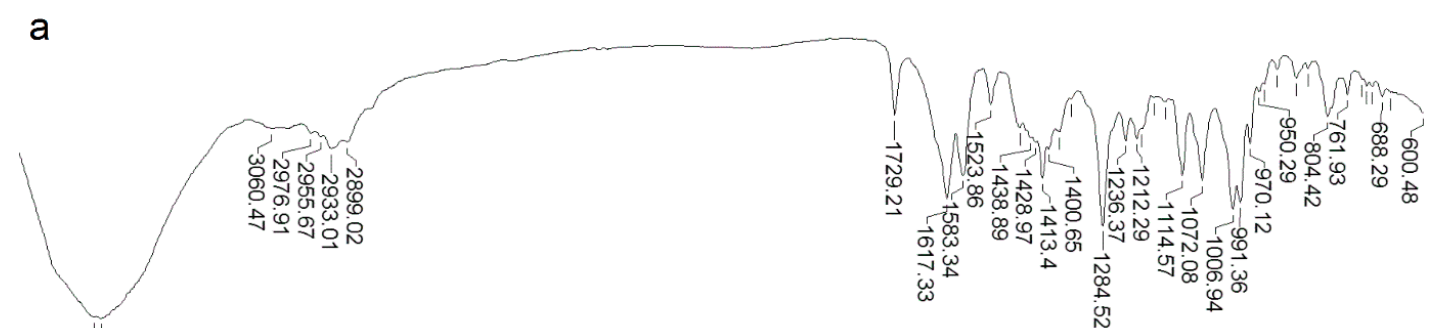

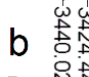
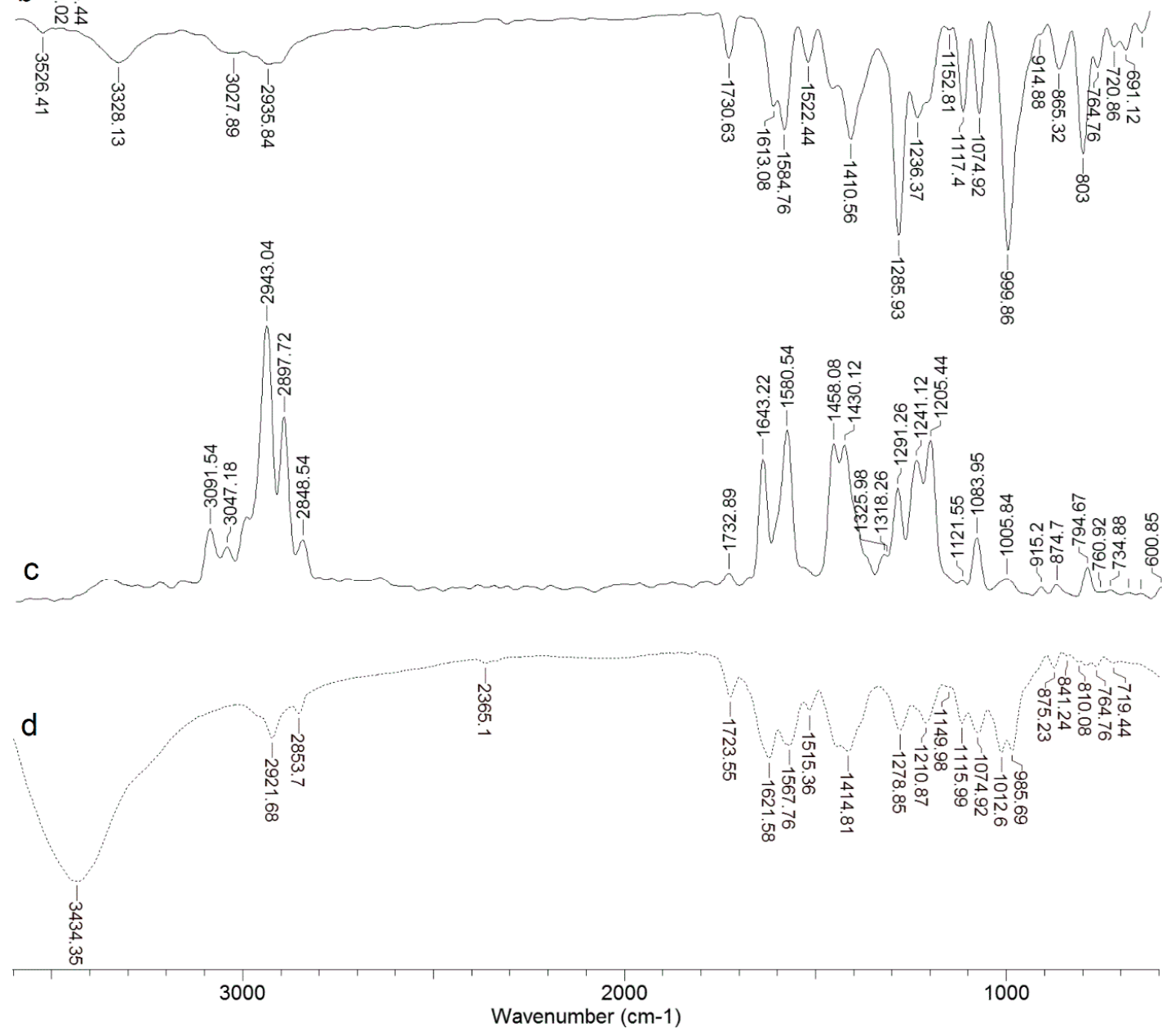

Figure 2. IR KBr (a) and ATR (b) and Raman (c) spectra of DOX (continuous lines) and IR KBr spectra of Cu-DOX complex (the dotted line) (d).

\subsection{Study on the Composition of Metal-DOX Complexes in Aqueous Solutions and Solid Phase}

The composition of DOX complexes with metals such as $\mathrm{Fe}(\mathrm{III}), \mathrm{Cu}(\mathrm{II}), \mathrm{Mn}(\mathrm{II}), \mathrm{Ni}(\mathrm{II}), \mathrm{Co}(\mathrm{II})$, $\mathrm{Mg}(\mathrm{II}), \mathrm{Zn}$ (II) was investigated. The complex composition in aqueous solution was tested in the presence of the buffer (Tris- $\mathrm{HCl}$ ) at $\mathrm{pH}$ 7.01. The results of the study on the composition of the complexes are depicted in Figures 3 and 4. Figure 3A shows the UV-VIS spectra of DOX and DOX complexes with copper, and in Figure 3B the changes in the maximal absorption of DOX by copper complexation are presented. An analytical band of $510 \mathrm{~nm}$ wavelength was selected. The other presented curves reflect the measurements carried out for the DOX solution after the addition of stoichiometric amounts of copper(II) chloride at a concentration of $0.01 \mathrm{M}$. Changes in the maximum absorbance of the resulting copper complex are shown in Figure 3. The maximum absorbance after addition of copper ions decreases sharply to 0.34 . The value is reached for a molar ratio of 1:2 (copper: 
DOX) and then falls slowly. As the amount of copper ions increases, the absorbance value of DOX decreases as a result of complexation. In the other solutions, where the amount of metal ions is higher than the metal: DOX 1:2 molar ratio, the absorbance decreases slightly. On the basis of the graphs of the absorbance ratios of the metal:DOX molar ratio it was found that copper forms a complex with DOX in a ratio of 1:2 (metal:DOX). Analogous measurements were conducted for DOX complexed with nickel, zinc, magnesium, cobalt, iron and manganese. Changes in the maximum of absorbance of DOX complexed with the investigated metals are shown in Figure 4. Based on the literature data and IR spectroscopy results the probable structures of the complexes were determined (Figure 5) [13,15-19,28]. In the IR spectra of the complexes, the bands associated with the oscillation of the hydroxyl group and the carbonyl group (e.g., bands at $970 \mathrm{~cm}^{-1}$ and $912 \mathrm{~cm}^{-1}$ in the doxorubicin spectrum) have been lost. The spectra of the selected complex (Cu-DOX) are shown in Figure 2. The spectral data are summarized in Table 2 In each of the analyzed complexes, the metal is attached to the DOX molecule by substituting the hydrogen atom of the hydroxyl group at $\mathrm{C}(24)$ and by the attaching to the oxygen atom of the carbonyl group C (27) (Figure 5). In the case of the Fe(III)-DOX complex, the metal coordinates three ligands, however the metal-ligand coordination mode is similar like in other studied metal-anthracyclin complexes (through the carbonyl group and the hydroxyl group).

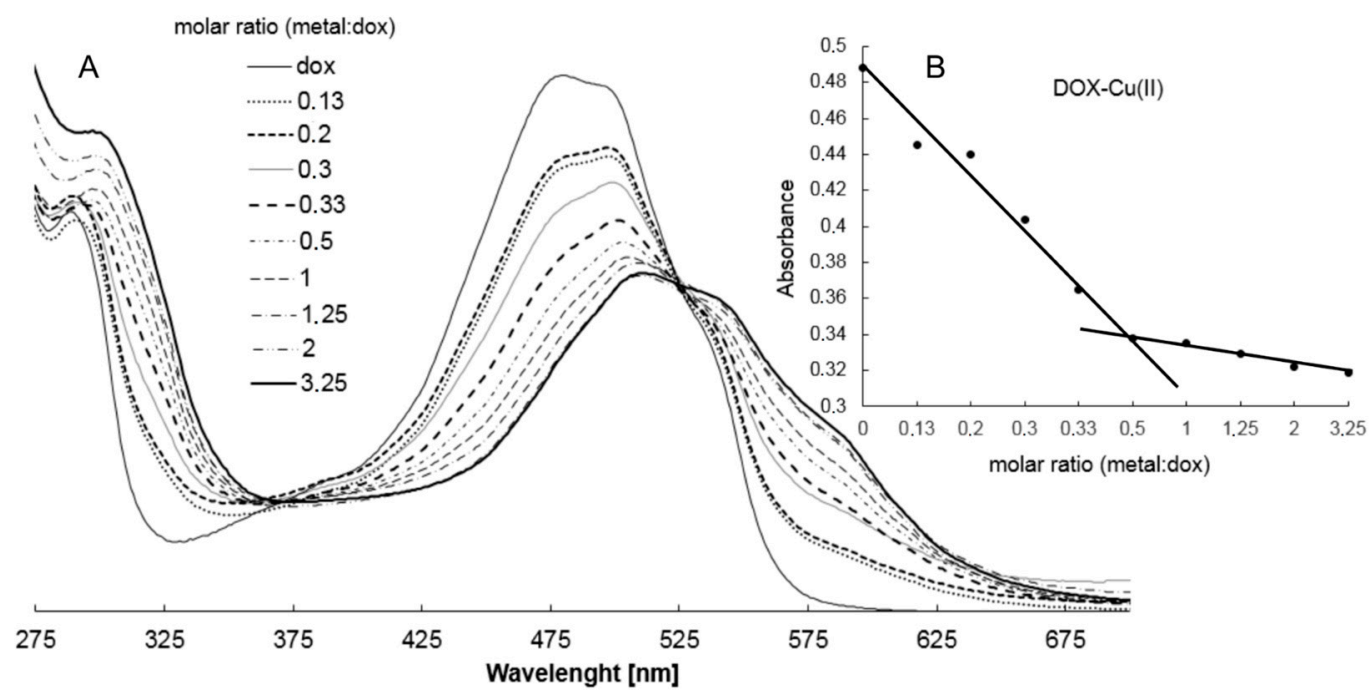

Figure 3. (A) Absorption spectra of DOX in the presence of various amounts of $\mathrm{Cu}(\mathrm{II})$ in Tris- $\mathrm{HCl}$ buffer pH 7.01 (different types of lines are labeled with a molar ratio $\mathrm{Cu}(\mathrm{II})$ :DOX 0.13-2.0); (B) absorbance as a function of $[\mathrm{Cu}(\mathrm{II})]:[\mathrm{DOX}]$ molar ratio at $500 \mathrm{~nm}$.
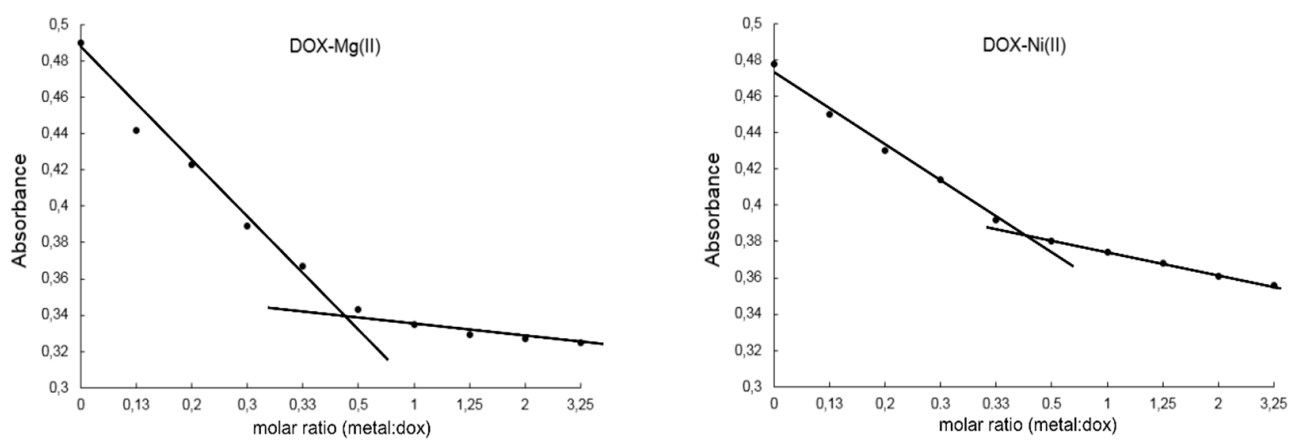

Figure 4. Cont. 

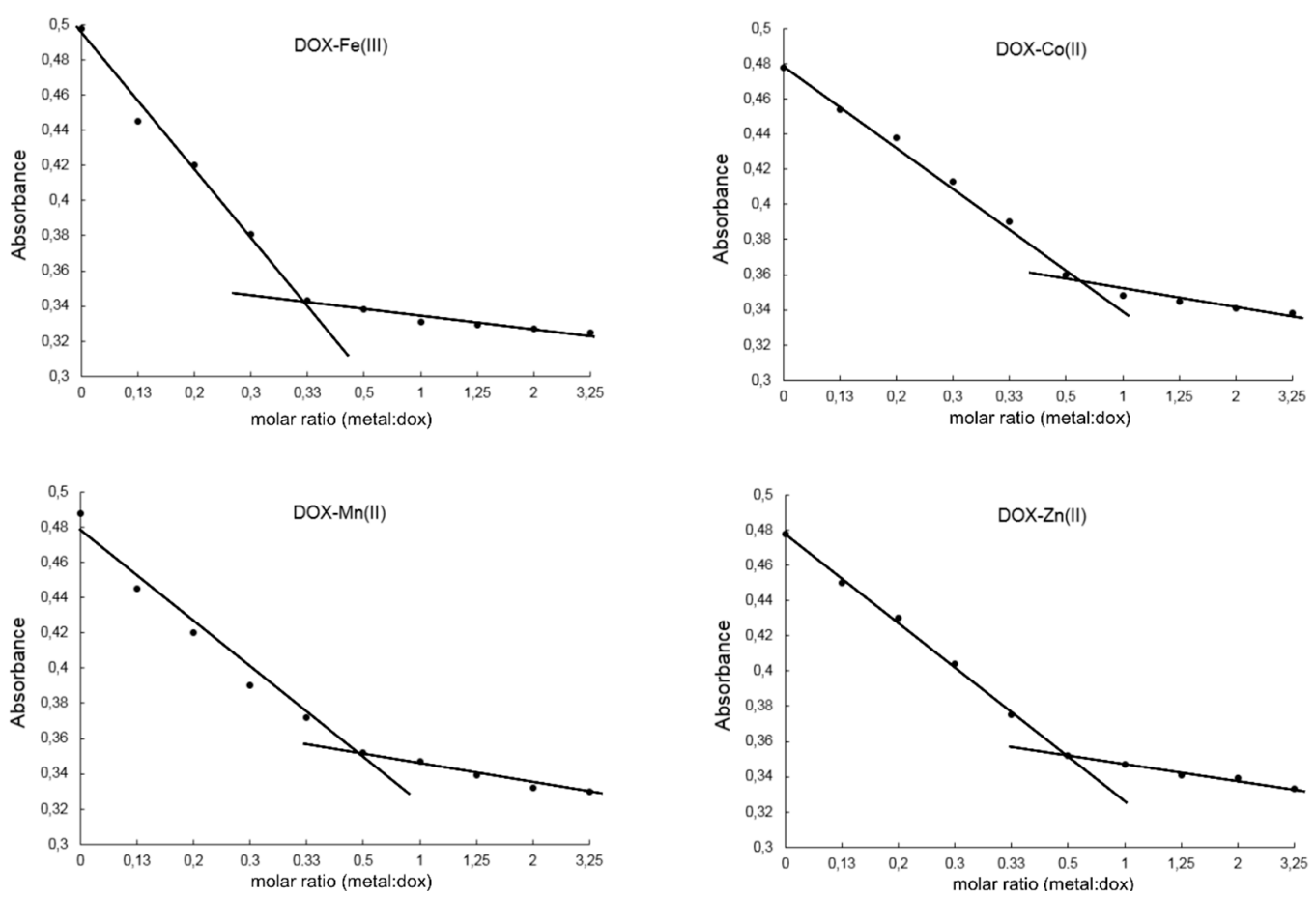

Figure 4. Absorbance as a function of [Metal]:[DOX] molar ratio at $500 \mathrm{~nm}$. Metal-Dox complexes are water-soluble and they were prepared in Tris-HCl buffer $\mathrm{pH} 7.01$.

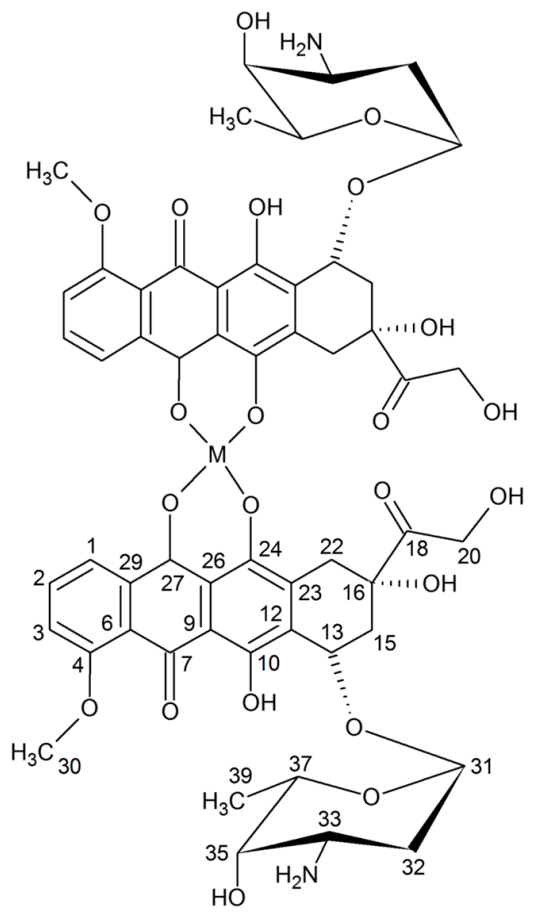

Figure 5. Proposal structure of complex metal-DOX.

\subsection{Estimation of Cells Proliferation}

In the cell proliferation assay, which is based on the integrity of cell membranes and it was conduct by using the Luna Logos Biosystem cell counter and trypan blue dye, a significant decrease in MCF-7 cancer cells proliferation was observed both as a result of incubation with doxorubicin and its 
complexes with selected metals. The most significant decreases in cells proliferation were observed in case of Mg-DOX, Mn-DOX and Ni-DOX in $0.5 \mu \mathrm{M}$ concentration after $24 \mathrm{~h}$ treatment. After $2 \mathrm{~h}$ and $4 \mathrm{~h}$ treatment, especially in lower concentrations of tested compounds no significant decreases in cells proliferation were observed. The influence of selected metals on cells proliferation after $2 \mathrm{~h}, 4 \mathrm{~h}$ and $24 \mathrm{~h}$ treatment is depicted in Figure 6.

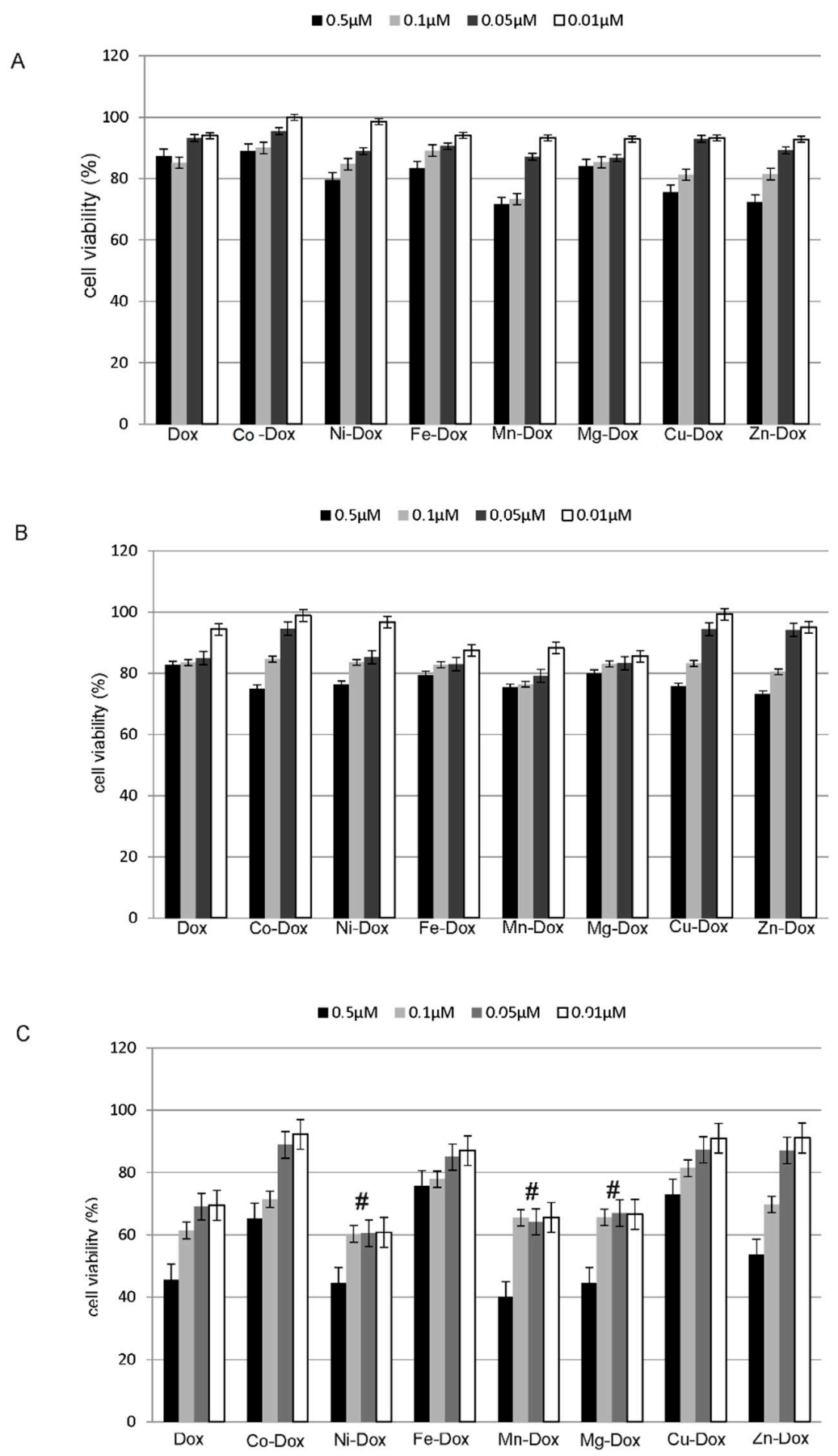

Figure 6. The effect of DOX, Cu-DOX, Zn-DOX, Co-DOX, Ni-DOX, Fe-DOX, Mn-DOX and Mg-DOX on cell proliferation of MCF-7 cells. The cells were incubated with $0.5 \mu \mathrm{M}, 0.1 \mu \mathrm{M}, 0.05 \mu \mathrm{M}$ and $0.01 \mu \mathrm{M}$ DOX and Metal-DOX complexes for $2 \mathrm{~h} \mathrm{(a),} 4 \mathrm{~h} \mathrm{(b)}$ and $24 \mathrm{~h}(\mathbf{c})$. Mean values from five independent experiments \pm SD are shown. Significant alterations are expressed relative to DOX-controls and marked with crosses (\#). Statistical significance was considered if \# $p<0.05$. 


\subsection{Estimation of Metals Cytotoxicity}

A CytoTox-Glo Cytotoxicity Assay (Promega) was used to assess the cytotoxic effects of the studied metal salts on MCF-7 cell line. The studied cells were exposed to different concentrations of $\mathrm{CuCl}_{2}, \mathrm{ZnCl}_{2}, \mathrm{CoCl}_{2}, \mathrm{NiCl}_{2}, \mathrm{FeCl}_{3}, \mathrm{MnCl}_{2}$ and $\mathrm{MgCl}_{2}$ for $24 \mathrm{~h}$. The tested concentrations were twice as low as the metal-DOX complexes concentrations. None of the tested compounds showed statistically significant increase in cytotoxicity (Figure 7).

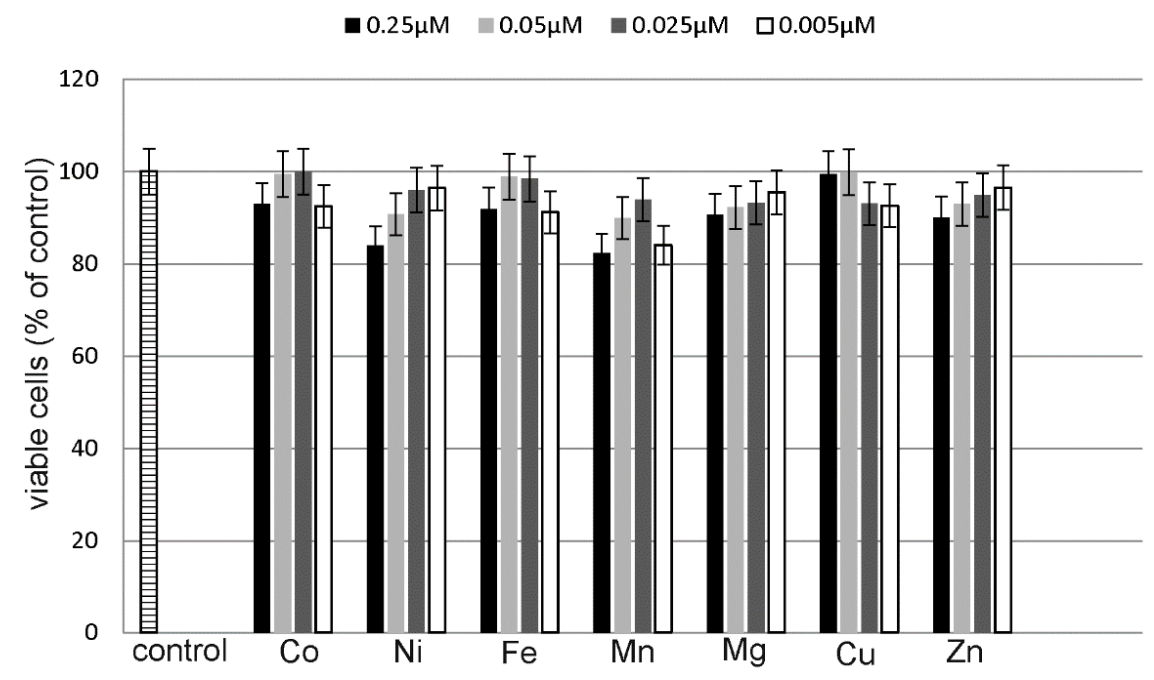

Figure 7. $\mathrm{Co}, \mathrm{Ni}, \mathrm{Fe}, \mathrm{Mn}, \mathrm{Mg}, \mathrm{Cu}$ and $\mathrm{Zn}$ cytotoxicity in MCF-7 cells. The cells were incubated with $0.25 \mu \mathrm{M}, 0.05 \mu \mathrm{M}, 0.025 \mu \mathrm{M}$ and $0.0005 \mu \mathrm{M}$ of metal chlorides for $24 \mathrm{~h}$. Mean values from five independent experiments \pm SD are shown. Results are statistically insignificant.

\subsection{Estimation of Cells Viability, Cytotoxicity and Apoptosis}

ApoTox-Glo ${ }^{\mathrm{TM}}$ Triplex Assay (Promega) was used to assess the apoptosis and cytotoxic effects of DOX and its metal complexes on MCF-7 cell line. The studied cells were exposed to different concentrations of DOX and Cu-DOX, Zn-DOX, Co-DOX, Ni-DOX, Fe-DOX, Mn-DOX and Mg-DOX for $24 \mathrm{~h}$. All of the tested compounds caused dose-dependent reduction in cells viability as compared to the control, non-treated cells (Figure 8). Particularly it was observed in case of $0.5 \mu \mathrm{M}$ concentration of Mg-DOX, Mn-DOX and Ni-DOX. Simultaneously, a significant increase in cytotoxicity of Mg-DOX, Mn-DOX and Ni-DOX $(0.5 \mu \mathrm{M})$ was noticed (Figure 9). Likewise, an increased level of apoptosis was observed in the presence of especially Mg-DOX, Mn-DOX and Ni-DOX $(0.5 \mu \mathrm{M})$. Exposure of MCF-7 cells to those three compounds significantly increased caspase 7 activity and thus apoptosis (Figure 10).

\subsection{Detection of Apoptosis and Necrosis}

An apoptosis in MCF-7 cells was estimated by using flow cytometry on FACSCanto II cytometer (Becton-Dickinson, San Diego, CA, USA). Figure 11 shows the percent of apoptotic and necrotic cells in cultures incubated for $24 \mathrm{~h}$ with DOX, Mg-DOX, Mn-DOX and Ni-DOX in $0.5 \mu \mathrm{M}$ concentration. We observed significant changes between the tested complexes. The concentration of $0.5 \mu \mathrm{M} \mathrm{Mn}-\mathrm{DOX}$ resulted in the most significant increase in apoptosis as compared to DOX-treated cells. We didn't observed significant changes between the tested metal complexes.

\subsection{Cell Cycle Analysis}

To investigate the connection between anti-proliferative activity of DOX and Ni-DOX, Mn-DOX and Mg-DOX $(0.5 \mu \mathrm{M}, 24 \mathrm{~h})$ and cell-cycle arrest, flow cytometry was used. Twenty four hour treatment with DOX-metal complexes: Mg-DOX, Mn-DOX and Ni-DOX in $0.5 \mu \mathrm{M}$ concentration, affected the cell 
cycle in studied cell line (Figure 12). A significant increase in the number of cells in G2/M phase with a simultaneous decrease in S and G1 phase was observed in all of the tested compounds as compared to DOX. The results were also referred to the control, non-treated cells. Analysis of flow cytometry results revealed also that MCF-7 cells cultured with DOX and its metal complexes showed significant differences in the distribution of cell cycle phases, with more pronounced effects observed in case of Mg-DOX than the other tested compounds.



Figure 8. The effect of DOX, Cu-DOX, Zn-DOX, Co-DOX, Ni-DOX, Fe-DOX, Mn-DOX and Mg-DOX on cell viability of MCF-7 cells. The cells were incubated with $0.5 \mu \mathrm{M}, 0.1 \mu \mathrm{M}, 0.05 \mu \mathrm{M}$ and $0.01 \mu \mathrm{M}$ DOX and Metal-DOX complexes for $24 \mathrm{~h}$. Mean values from five independent experiments $\pm \mathrm{SD}$ are shown. Significant alterations are expressed relative to control untreated cells (marked with asterisks *) and to DOX - controls (marked with crosses \#). Statistical significance was considered if *\# $p<0.05$.



Figure 9. DOX, Cu-DOX, Zn-DOX, Co-DOX, Ni-DOX, Fe-DOX, Mn-DOX and Mg-DOX cytotoxicity in MCF-7 cells. The cells were incubated with $0.5 \mu \mathrm{M}, 0.1 \mu \mathrm{M}, 0.05 \mu \mathrm{M}$ and $0.01 \mu \mathrm{M}$ DOX and Metal-DOX complexes for $24 \mathrm{~h}$. Mean values from five independent experiments \pm SD are shown. Significant alterations are expressed relative to control untreated cells (marked with asterisks *) and to DOX—controls (marked with crosses \#). Statistical significance was considered if \#* $p<0.05$. 




Figure 10. The effect of DOX, Cu-DOX, Zn-DOX, Co-DOX, Ni-DOX, Fe-DOX, Mn-DOX and Mg-DOX on apoptosis in MCF-7 cells. The cells were incubated with $0.5 \mu \mathrm{M}, 0.1 \mu \mathrm{M}, 0.05 \mu \mathrm{M}$ and $0.01 \mu \mathrm{M}$ DOX and Metal-DOX complexes for $24 \mathrm{~h}$. Mean values from five independent experiments \pm SD are shown. Significant alterations are expressed relative to control untreated cells (marked with asterisks *) and to DOX-controls (marked with crosses \#). Statistical significance was considered if *\# $p<0.05$.

\section{$24 h$}

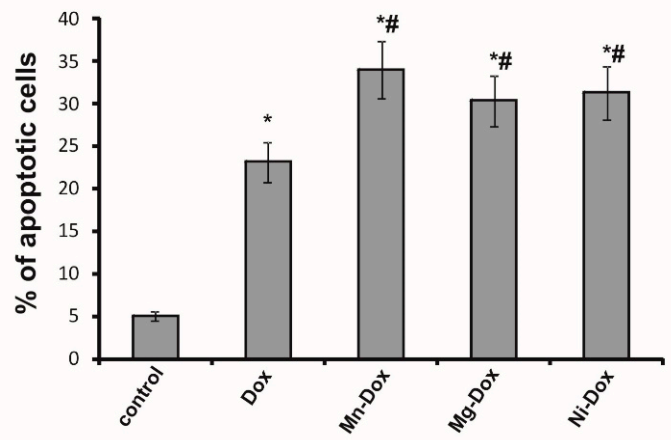

A

$24 h$

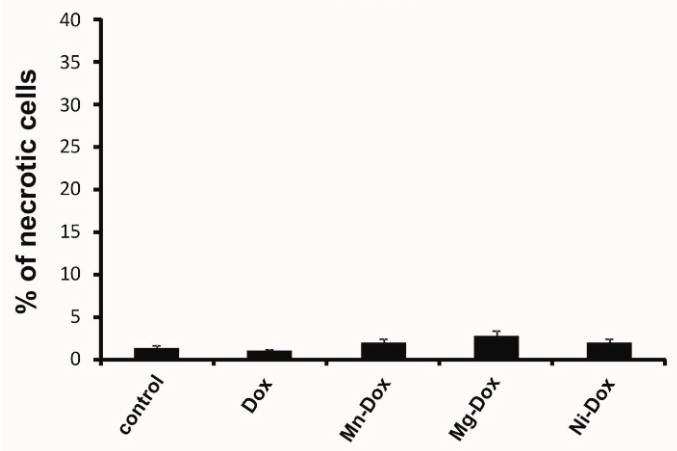

Figure 11. The effect of DOX, Ni-DOX, Mn-DOX and Mg-Dox on apoptosis of MCF-7 cells. The cells were incubated with $0.5 \mu \mathrm{M}$ DOX, Ni-DOX, Mn-DOX and Mg-DOX for $24 \mathrm{~h}$. Bar graphs presenting the percentage of apoptotic MCF-7 (A) and necrotic MCF-7 (B) cells, are demonstrated. Mean values from five independent experiments \pm SD are shown. Significant alterations are expressed relative to control and marked with asterisks $\left({ }^{*}\right)$; significant alterations are expressed relative to DOX-control and marked with crosses (\#). Statistical significance was considered if *\#p $p<0.05$. 




Figure 12. The effect of DOX, Ni-DOX, Mn-DOX and Mg-DOX on cell cycle distribution of MCF-7 cell line. The cell cycle was measured by propidium iodide staining followed by flow cytometry analysis. Results are shown for cells treated with $0.5 \mu \mathrm{M}$ Ni-DOX, Mn-DOX and Mg-DOX for $24 \mathrm{~h}$ versus untreated controls and versus $0.5 \mu \mathrm{M}$ DOX. Graphical representation of the cell cycle profiles obtained from flow cytometry measurements in MCF-7 cells is depicted in (A). Bar graph presenting the percentage of cell cycle distribution in MCF-7 after $24 \mathrm{~h}$ (B) of treatment with DOX, Ni-DOX, Mn-DOX and $\mathrm{Mg}$-DOX. Significant alterations are expressed relative to control and marked with asterisks $\left(^{*}\right)$; significant alterations are expressed relative to DOX-control and marked with crosses (\#). Statistical significance was considered if *\#p $p 0.05$. 


\section{Discussion}

The success of cisplatin has led to increased interest in other metal complexes as potential anticancer agents. Especially metals, such as zinc, copper, iron, manganese and others, which are involved in variety of biological processes, are increasingly applied to treating multiple disorders including different types of cancer [29,30]. One of the very important metal features is the fact that in aqueous solutions they have the ability to form positively charged ions that might bind to negatively charged molecules. Therefore the charge can be changed depending on the coordination environment, which leads to the generation of cationic, anionic or neutral species. Moreover, metal ions that are characterized by high electron affinity can polarize groups coordinated to them, promoting hydrolysis reactions [31]. Compounds that contain metals in their structure have many advantages in contrast to traditional carbon-based agents. These benefits mainly due to the fact that they have the ability to coordinate ligands in a three dimensional structure and therefore the functional groups can be adapted to the molecular targets. Complexes, in which metals are involved, can create an environment that favors the building of many different molecular structures that endow a wide range of coordination numbers and geometries and kinetic properties [32-34].

Complexation of DOX with metals has been the subject of numerous studies described in the literature. Feng et al. studied DOX complexes with copper(II) and iron(II) [9]. Spectroscopy (UV-Vis) and spectrofluorometry showed that DOX was complexed with copper in a ratio of 2:1 and with an iron in a ratio of 3:1. DOX was complexed with an iron and copper ions at $\mathrm{pH}=7$ in Tris- $\mathrm{HCl}$ buffer. According to the literature metal-DOX complexes exhibit different stability, e.g., doxorubicin complex with iron(III) shows higher stability than the copper complex [9,18]. Studies by Benny et al. have demonstrated that DOX complexed with manganese at $\mathrm{pH} 7$ (HEPES buffer) forms a ligand:metal complex in a 2:1 ratio [28]. The formation of $\mathrm{Mn}(\mathrm{II})$-doxorubicin complexes, with a high stability constant $\left(\mathrm{p} K_{d}=7.0\right)$ has been also described [28]. Literature data show that the complexation of doxorubicin with metal ions can increase the cytotoxic properties of the drug and enhance the accumulation of drug in the cells. Available literature data indicate that much attention has been paid to the study of the activity of doxorubicin complexes with DNA. It has been shown that complexes with $\mathrm{Fe}^{3+}$ and $\mathrm{Cu}^{2+}$ ions facilitate the binding of doxorubicin to DNA. In addition, they increase the generation of reactive oxygen species, which enhances their cytotoxic effects $[11,17,35]$. The results of literature studies show that the complexation of doxorubicin with metal ions $\left(\mathrm{Mn}^{2+}\right)$ increases the accumulation of drug in liposomes [36,37].

Furthermore not all of the anthracyclines are able to bind to the selected metal ions. In the case of aclarubicin it is not possible to complex with $\mathrm{Fe}(\mathrm{III})$ or $\mathrm{Pd}(\mathrm{II})$ ions due to the absence of the phenol groups at the $\mathrm{C}-11^{\prime}$ position of the aglycone ring [18]. Various ways of metal binding is also apparent from its intrinsic properties. For instance $\mathrm{Cu}(\mathrm{II})$ : carminomycin complex is formed in a molar ratio of 1:2, while in the case of aclacinomycins: $\mathrm{Cu}(\mathrm{II})$ : ACLA complexes may occur in two molar ratios: 1:2 and 1:1. In both described complexes an antiferromagnetic connection between the copper ions, even in aqueous solutions, exists [38]. Studies on the interactions of various metal ions essential for living organisms with anthracycline antibiotics allow for a better understanding of the drugs in vivo mechanisms of action.

Metal ions are extremely important in many metabolic processes at the cellular level and the level of the whole organism. One of the important microelements is iron, which is involved in redox reactions, that are associated with the formation of free radicals in the presence of the dioxygen and cause damage to the cell structures. Anthracyclines bind iron to form a drug-metal complexes with a molar ratio of 1:1, 1:2 or 1:3. DOX is able to directly attach iron, and additionally, in the presence of oxygen affects the state of iron oxidation (Fe(II)-Fe(III) cycle). It has been shown that the $\mathrm{Fe}^{3+}$ ion can bind three anthracycline molecules in aqueous solution, wherein the metal is chelated by the $11,12-\beta$-ketophenol group [13]. Our results revealed that bivalent metals at a given $\mathrm{pH}$ condition can complex metal: DOX at a ratio 2:1 while iron with DOX complexes in a 3:1 ratio. 
For the evaluation of cytotoxicity induced by DOX and metals-DOX complexes Apo-Tox GloTM Assay and Luna Logos Biosystems cell counter were used. In our study we observed that metal-DOX complexes are potent inhibitors of MCF-7 cells proliferation. To confirm our results we studied also the influence of all tested metal chlorides in twice lower concentrations than metal-DOX complexes on MCF-7 cell line. Obtained results indicate that simple metal salts don't exhibit any cytotoxic properties in studied breast cancer cells, therefore we conclude that only the connection of metal with DOX is effective in decreasing of MCF-7 cell viability. We also noticed that the decrease in cell viability was in accordance with reduced cell proliferation. Obtained results indicate that MCF-7 cell viability was clearly decreased in a dose-dependent manner. By the use of the direct count method we observed the most significant decreases in cell viability after $24 \mathrm{~h}$ treatment especially with Mg-DOX, Mn-DOX and Ni-DOX complexes in $0.5 \mu \mathrm{M}$ concentration. The study performed with the use of ApoTox GloTM Assay after 24-h treatment confirmed the obtained results. $2 \mathrm{~h}$ and $4 \mathrm{~h}$ treatment didn't change significantly cell number or viability. This is consistent with the results of previous studies of Lange et al., demonstrating unique properties of transition metal-based complexes against cancer cells. Excellent anti-proliferative properties exhibit complexes of transition metals, e.g., iron or copper. An example might be here ferrocifenes that manifest anticancer activity against hormone- dependent and hormone-independent breast cancers [39-41]. Copper complexes also show anticancer activity which results from their ability to produce reactive oxygen species. According to the literature the highest efficacy reveals copper complexes, where pyridine-type ligands (pyridine, bipyridine, phenanthroline, etc.) are present or such where copper(I) ion is coordinated to phosphine ligands [42]. In our research copper-DOX complexes weren't as efficient in cell proliferation inhibition as magnesium or nickel compounds. However, what is important, the effectiveness of metal-DOX complexes against MCF-7 cells hasn't been under investigation yet. Zinc and copper were also in our investigation of complexes with DOX. According to Milacic et al. these two metals in complexes with pyrrolidine diothiocarbamate showed a significantly high potency in inhibiting the $26 \mathrm{~S}$ proteasome in intact breast cancer cells [43]. We didn't observe a significant changes in cell viability, proliferation and apoptosis under the influence of zinc and copper complexes with DOX as compared to free DOX.

The induction of apoptosis in susceptible target cell occurs via the initiation of the death signaling pathways by the cytotoxic agents, such as DOX. Simultaneous or consequent activation of death receptor systems, alterations in mitochondrial function and proteolytic processing of caspases are associated with the activation of apoptosis process by the chemotherapeutic agents [44]. Our results point to the fact that tested compounds, except for zinc and copper-DOX complexes, have caused a significant apoptosis evaluated by caspase $3 / 7$ protein expression in ApoTox Glo ${ }^{\mathrm{TM}}$ Assay, which was confirmed for three of the most significant results (Mg-DOX, Mn-DOX and Ni-DOX) by flow cytometry. However, the activity of caspase 3 wasn't detected in MCF-7 cell line because they do not express detectable levels of caspase-3. Despite the fact that MCF-7 lack the expression of executor caspase 3 known as CPP32, Yama, or apopain, they undergo apoptosis after treatment with anticancer agents. The studied cell line has confirmed $47 \mathrm{~kb}$ deletion in exone 3 of the CPP32 gene. However, it appears that not only the activation of caspase 3, but also caspase 7 by the action of initiator caspases 8 and 9 , enhances the apoptosis process. Caspase 7 is strongly associated with caspase 3 and they exhibit the same in vitro substrate specificity [45]. According to McGee et al caspase-3-independant apoptosis could be activated by other effector caspases and then they may overtake the function of caspase- 3 in apoptosis enhancement in MCF-7 cells [46]. Our results are in accordance with literature data describing the influence of DOX on executioner caspases activation. Cuvillier et al. showed that the treatment of human breast carcinoma MCF-7 cells with DOX induces apoptosis through cytochrome c release from the mitochondria and activation of the executioner caspase-7 in MCF7 cells which do not express caspase-3 [47]. Additionally we found out that DOX complexed with selected metals is more effective in apoptosis induction than a parent drug. It has been reported that treatment with the other post-transition metal-gallium, which according to its electric charge, ion diameter and electronic configuration is similar to that of $\mathrm{Fe}^{3+}$ (transition metal), results in cytochrome c release from 
the mitochondria, activation of caspase-3 and morphologic changes of apoptosis in human lymphoma cells $[48,49]$. Therefore we conclude that MCF-7 cell underwent apoptosis under the influence of selected metals-DOX complexes in $0.5 \mu \mathrm{M}$ concentration after $24 \mathrm{~h}$ treatment through the activation of the executioner caspase-7, despite the lack of caspase-3. A constantly emerging topic in anticancer drug research is the development of new compounds that target the cell-cycle checkpoints, which are responsible for the control of the cell-cycle phase progression. For example defects in the G2/M arrest checkpoint may permit a damaged cell to enter mitosis and undergo apoptosis. All of the studies on increasing this effect may enhance cytotoxicity and effectiveness of chemotherapy. The progression of the cell cycle which includes all phases: G1 phase, S phase (DNA replication), G2 phase, and M phase (mitosis and cytokinesis) is essential for cell growth and development. For controlling unlimited growth and cells proliferation, two check points at G1 and G2 phases are important. In cancer cells G2 phase is often intact and left to be critical in cell survival [50]. In order to monitor the connection between cell-cycle arrest, apoptosis and the anti-proliferative effect of metal-DOX complexes in MCF-7 flow cytometry was used. Obtained results indicate that the tested metal-DOX complexes affected the cell cycle. After $24 \mathrm{~h}$ treatment with Mn-DOX, Mg-DOX and Ni-DOX in $0.5 \mu \mathrm{M}$ concentration there was a significant increase in the G2/M phase in comparison to the control and to the DOX-treated cells. We conclude that above described growth and proliferation inhibitory effect of $0.5 \mu \mathrm{M} \mathrm{Mg-DOX,} \mathrm{Mn-DOX}$ and Ni-DOX on MCF-7 breast cancer cells is associated with a G2/M arrest in cell cycle progression and with induction of apoptosis. One of the possible mechanisms that explains this phenomenon is the fact that metal-DOX complexes are capable of enhancing cytotoxicity in association with enhanced checkpoints arrest. In the report by Tyagi et al., DOX in combination with silibinin, a derivative of milk thistle, induced increased G2/M arrest and modulated G2/M cell cycle regulators [51]. The results obtained by Tyagi et al. point to the fact that down-regulation of the G2/M cell cycle regulators and G2/M arrest could be a possible mechanism for the effect of DOX on cell growth and apoptosis. A similar mechanism could be responsible for the effect that we observed under the influence of selected transition metals complexed with DOX. To confirm the thesis concerning the importance of cell cycle arrest to DOX cytotoxicity, Ling et al. showed that P388 cells synchronized in S and G2-M phases were characterized by higher sensitivity to DOX than cells in G1 phase [52]. The other literature data also indicate that DOX induces dose-dependent G2/M arrest and that cells in this phase are particularly sensitive to chemical drugs [53].

Although many molecular and cell effects of DOX have been described, including cytotoxicity, apoptosis induction, cell cycle analysis, the ability of selected metals-DOX complexes, e.g., Mg-DOX, Mn-DOX and Ni-DOX complexes to decrease cancer cell viability and to significantly induce apoptosis in MCF-7 cells was demonstrated for the first time. The obtained results led us to the conclusion that DOX-metal complexes may be considered as a potential, new anticancer agents with higher efficacy than free DOX. However further research concerning metal-DOX complexes molecular mechanisms of action and possible changes in oxidative stress signaling pathways under the influence of tested compound are needed.

\section{Materials and Methods}

\subsection{Reagents}

Dulbecco's modified Eagle's medium (DMEM), containing glucose at $4.5 \mathrm{mg} / \mathrm{mL}(25 \mathrm{mM})$ with Glutamax, penicillin, streptomycin, trypsin-EDTA, FBS Gold and PBS (without Ca and Mg) were provided by Gibco (San Diego, CA, USA). Trypan Blue dye was provided by Sigma-Aldrich (Saint Louis, MO, USA). ApoTox-Glo ${ }^{\mathrm{TM}}$ Triplex Assay was provided by Promega (Madison, WI, USA), fluorescein isothiocyanate (FITC) Annexin V Apoptosis Detection Kit I was by BD Pharmingen (San Diego, CA, USA). DOX hydrochloride was obtained from Sigma-Aldrich. Metal chlorides: $\mathrm{CuCl}_{2} \cdot 2 \mathrm{H}_{2} \mathrm{O}_{\text {, }}$ $\mathrm{ZnCl}_{2}, \mathrm{MnCl}_{2} \cdot 4 \mathrm{H}_{2} \mathrm{O}, \mathrm{MgCl}_{2} \cdot 6 \mathrm{H}_{2} \mathrm{O}, \mathrm{NiCl}_{2} \cdot 2 \mathrm{H}_{2} \mathrm{O}, \mathrm{CoCl}_{2} \cdot 6 \mathrm{H}_{2} \mathrm{O}, \mathrm{FeCl}_{3} \cdot 4 \mathrm{H}_{2} \mathrm{O}$, and Tris- $\mathrm{HCl}$ buffer were provided by Sigma-Aldrich. 


\subsection{Complexes Preparation}

Doxorubicin $(0.02 \mathrm{mM})$ was weighed and dissolved in $10 \mathrm{~mL}$ water. $\mathrm{NaOH}$ was added to the solution to provide a slightly alkaline $\mathrm{pH}$. Thereafter, the stoichiometric amount of aqueous solution of metal chloride was continuously added under stirring for one hour. The reaction mixture was then stirred for $72 \mathrm{~h}$ at room temperature. The obtained solution was incubated for several days to precipitate the sediment complexes. After precipitation, the complexes were filtered with water and dried under vacuum. Elemental composition of the complexes was determined. The obtained complexes had $\left(\mathrm{C}_{27} \mathrm{H}_{27} \mathrm{NO}_{11}\right)_{2} \mathrm{M}$ composition (anhydrous complexes), where $\mathrm{M}=\mathrm{Cu}, \mathrm{Mg}$ and $\mathrm{Ni}$ : for the copper complex: $\% \mathrm{C}=56.51 / 56.83$ (calc/exp) and $\% \mathrm{H}=4.71 / 4.59$; magnesium complex: $\% \mathrm{C}=58.57 / 59.18$ (calc/exp) and $\% \mathrm{H}=4.88 / 5.06$; nickel complex: $\% \mathrm{C}=56.81 / 56.53$ (calc/exp) and \%H = 4.73/4.43; $\left(\mathrm{C}_{27} \mathrm{H}_{27} \mathrm{NO}_{11}\right)_{2} \mathrm{M} \cdot 0.5 \mathrm{H}_{2} \mathrm{O}$ composition for cobalt complex: \%C $=56.35 / 56.33$ (calc/exp) and \%H = 4.78/4.49; $\left(\mathrm{C}_{27} \mathrm{H}_{27} \mathrm{NO}_{11}\right)_{3} \mathrm{Fe} \cdot 0.5 \mathrm{H}_{2} \mathrm{O}$ composition for the iron complex: $\% \mathrm{C}=57.58 / 57.42$ (calc/exp) and $\% \mathrm{H}=4.85 / 4.61$ (calc/exp) and $\left(\mathrm{C}_{27} \mathrm{H}_{27} \mathrm{NO}_{11}\right)_{2} \mathrm{M} \cdot \mathrm{H}_{2} \mathrm{O}$, where $\mathrm{M}=\mathrm{Zn}, \mathrm{Mn}$ : for the zinc complex: $\% \mathrm{C}=55.6 / 55.39$ (calc/exp) and $\% \mathrm{H}=4.81 / 4.42$; and manganese complex: $\% \mathrm{C}=56.10 / 56.23$ (calc/exp) and $\% \mathrm{H}=4.84 / 4.91$. IR spectra were also recorded. The obtained complexes are water-soluble.

\subsection{Infrared Spectrum (FT-IR, ATR) and Raman Spectrum of DOX and Metal Complexes}

The FT-IR spectra for DOX hydrochloride were recorded with an Alfa spectrometer (Bruker, Billerica, MA, USA) within the range of $400-4000 \mathrm{~cm}^{-1}$. Samples in the solid state were measured in $\mathrm{KBr}$ matrix pellets and ATR technique. FT-Raman spectra of solid samples were recorded in the range of $400-4000 \mathrm{~cm}^{-1}$ with a MultiRam (Bruker) spectrometer. Experimental spectra were interpreted in terms of literature data [54]. IR spectra $(\mathrm{KBr})$ metal complexes were also registered to determine metal-ligand coordination mode.

\subsection{Study on the Composition of Metal-DOX Complexes in Aqueous Solutions}

Aqueous solutions of $\mathrm{CuCl}_{2}, \mathrm{FeCl}_{3}, \mathrm{ZnCl}_{2}, \mathrm{MgCl}_{2}, \mathrm{MnCl}_{2}, \mathrm{CoCl}_{2}$ and $\mathrm{NiCl}_{2}$ at concentrations of $0.01 \mathrm{~mol} / \mathrm{L}$ were prepared for the study of complex composition in the aqueous solutions. DOX solution $(50 \mu \mathrm{mol} / \mathrm{L})$ was prepared in TRIS- $\mathrm{HCl}$ buffer at $0.02 \mathrm{~mol} / \mathrm{L}$ and $\mathrm{pH} 7.01$. Composition of DOX complexes with metals was determined by spectrophotometric titration. Three $\mathrm{mL}$ of DOX solution in buffer was poured into the cuvette (quartz) and the absorbance of the solution against the reference TRIS-HCl buffer was measured. A solution of metal chloride at a concentration of $0.01 \mathrm{~mol} / \mathrm{L}$ was then added in the amounts shown in Table 3.

Table 3. Quantities of DOX and metal chloride.

\begin{tabular}{cccc}
\hline Sample Number & Molar Ratio Metal:DOX & DOX $(\mathbf{m L})$ & Metal Chloride $(\mu \mathrm{L})$ \\
\hline 1 & 0 & 3 & 0 \\
2 & 0.13 & 3 & 2 \\
3 & 0.2 & 3 & 3 \\
4 & 0.3 & 3 & 4 \\
5 & 0.33 & 3 & 5 \\
6 & 0.5 & 3 & 7.5 \\
7 & 1 & 3 & 15 \\
8 & 1.25 & 3 & 20 \\
9 & 2 & 3 & 30 \\
10 & 3.25 & 3 & 50 \\
\hline
\end{tabular}

After each addition, the solution was stirred in the cuvette and the absorbance of the solution was measured. DOX was complexed with iron, copper, cobalt, manganese, nickel, magnesium and zinc at $\mathrm{pH}$ 7.01. For complexes with fixed composition in solution, the measurement was repeated after $24 \mathrm{~h}$ 
to determine the stability of the complexes. UV-VIS spectra were recorded in the range of 190-800 nm with a HACH 2000 spectrometer (HACH Company, Loveland, CO, USA).

\subsection{Cell Culture}

The effect of DOX, Cu-DOX, Zn-DOX, Co-DOX, Ni-DOX, Fe-DOX, Mn-DOX and Mg-DOX was examined in MCF-7 breast cancer cell line, which were obtained from the American Type Culture Collection (ATCC, University Boulevard, Manassas, VA, USA). Cells were maintained in DMEM supplemented with $10 \%$ FBS, penicillin $(100 \mathrm{U} / \mathrm{mL})$, and streptomycin $(100 \mu \mathrm{g} / \mathrm{mL})$ at $37{ }^{\circ} \mathrm{C}$ in a humified atmosphere of $5 \% \mathrm{CO}_{2}$ in air. Adherent cells $\left(2 \times 10^{5}\right.$ cells $\left./ \mathrm{mL}\right)$ in $2 \mathrm{~mL}$ of culture medium were incubated with the test compounds in tissue culture 6-well plates. MCF-7 cells $\left(2 \times 10^{4}\right.$ cells $\left./ \mathrm{mL}\right)$ in $200 \mu \mathrm{L}$ of culture medium were incubated without and with the test compounds in tissue culture treated black 96-well plates for the ApoTox-Glo Assay. The cells proliferation, viability, cytotoxicity and apoptosis were estimated at Dox, Cu-DOX, Zn-DOX, Co-DOX, Ni-DOX, Fe-DOX, Mn-DOX and Mg-DOX concentration of $0.5 \mu \mathrm{M}, 0.1 \mu \mathrm{M}, 0.05 \mu \mathrm{M}$ and $0.01 \mu \mathrm{M}$. Detection of apoptosis and necrosis and cell cycle analysis were conducted with DOX and selected metal-DOX complexes: Ni-DOX, $\mathrm{Mn}-\mathrm{DOX}$ and $\mathrm{Mg}$-DOX concentration of $0.5 \mu \mathrm{M}$.

\subsection{Cell Exposure to DOX and Its Metal Complexes}

DOX, Cu-DOX, Zn-DOX, Co-DOX, Ni-DOX, Fe-DOX, Mn-DOX and Mg-DOX were stored in a refrigerator at temperature $4{ }^{\circ} \mathrm{C}$. The compounds were added to the cultured cells for a final concentration in the range of $0.01 \mu \mathrm{M}$ to $0.5 \mu \mathrm{M}$. Concentration range was selected for the experiments on the basis of previously established data. According to the literature data at DOX concentrations of $0.05 \mu \mathrm{M}, 0.1 \mu \mathrm{M}$ and $0.5 \mu \mathrm{M}$ MCF-7 cells growth is inhibited by approximately 15,50 , and $75 \%$, respectively [55]. The control cells were incubated for $24 \mathrm{~h}$ with and without the test compounds for: the ApoTox-Glo ${ }^{\mathrm{TM}}$ assay, the estimation of the cells proliferation by using cell counter, cell cycle analysis and apoptosis and necrosis detection.

\subsection{Estimation of Cells Proliferation}

The number MCF-7 cells with division into living and dead after $2 \mathrm{~h}, 4 \mathrm{~h}$ and $24 \mathrm{~h}$ treatment, was determined by direct counts of cells with the use of trypan blue dye using a LUNA Logos Biosystems cell counter.

\subsection{Estimation of Metals Cytotoxicity}

To measure metal chlorides cytotoxicity CytoTox-Glo Cytotoxicity Assay (Promega Corporation, Madison, WI, USA) was used. The measurement was conducted according to manufacturer's protocol. In brief, assay uses a luminogenic peptide substrate (alanyl-alanyl-phenylalanyl-aminoluciferin; AAF-Glo ${ }^{\text {TM }}$ Substrate) to measure "dead-cell protease activity", which is released from cells that have lost membrane integrity. Substrate cannot cross the intact membrane of live cells, therefore the assay detects dead cells and relies on the properties of a proprietary thermostable luciferase. Applied luciferase uses aminoluciferin as a substrate to generate a stable "glow-type" luminescent signal. Luminescence was measured with a GloMax ${ }^{\circledR}$-Multi Microplate Multimode Reader plate reader (Promega Corporation, Madison, WI, USA).

\subsection{Estimation of Cells Viability, Cytotoxicity and Apoptosis}

To measure MCF-7 cells viability, cytotoxicity and apoptosis, the ApoTox-Glo ${ }^{\mathrm{TM}}$ Triplex Assay (Promega) was used. All the measurements were conducted on the same sample according to manufacturer's protocol. In brief, in the first part two protease activities were measured simultaneously as a markers of cells viability and cytotoxicity. After adding an appropriate substrate: GF-AFC (for viability) and bis-AAF-R110 (for cytotoxicity), live-cell or dead-cell proteases cleave added compound 
and fluorescent signal is produced. Apoptosis was measured after the addition of a luminogenic caspase $3 / 7$ substrate (Caspase Glo 3/7), which is subsequently cleaved in apoptotic cells to produce a luminescent signal. Fluorescence at 365 Ex/500 Em (viability), 485 Ex/535 Em (cytotoxicity) and luminescence (apoptosis) were measured with a GloMax ${ }^{\circledR}$-Multi Microplate Multimode Reader plate reader.

\subsection{Detection of Apoptosis and Necrosis}

The MCF-7 cells were exposed to DOX and Ni-DOX, Mn-DOX and Mg-DOX in the high glucose DMEM for $24 \mathrm{~h}$. Apoptosis and necrosis were evaluated by flow cytometry on FACSCanto II cytometer (Becton-Dickinson). The cells were trypsinised and resuspended in DMEM. After that time, the cells were suspended in binding buffer for staining with FITC-Annexin V and propidium iodide-PI for $15 \mathrm{~min}$ at room temperature in the dark following the manufacturer's instructions (FITC Annexin V apoptosis detection Kit I). The signal obtained from cells stained with annexin V or PI alone was used for fluorescence compensation. Data were analyzed with FACSDiva software.

\subsection{Cell Cycle Assay}

The MCF-7 cells were exposed to DOX and Ni-DOX, Mn-DOX and Mg-DOX in the high glucose DMEM for $24 \mathrm{~h}$. Subsequently the cells were trypsinized and resuspended in cold PBS. Cells $\left(1 \times 10^{6}\right)$ were collected by centrifugation at $1000 \mathrm{rpm}$ for $5 \mathrm{~min}$. The cell pellets were washed twice with cold PBS and resuspended approximately with $100 \mu \mathrm{L}$ of cold PBS. The cell pellets were fixed with ice cold $70 \%$ ethanol for minimum $1 \mathrm{~h}$ at $4{ }^{\circ} \mathrm{C}$. The fixed cells were centrifuged at $1200 \mathrm{rpm}$ for $5 \mathrm{~min}$. Following, the cell pellets were washed twice with cold PBS and resuspended in the $38 \mathrm{mM}$ sodium citrate, containing $120 \mu \mathrm{g} / \mathrm{mL}$ RNAse A and $10 \mu \mathrm{g} / \mathrm{mL}$ propidium iodide at $37^{\circ} \mathrm{C}$ for $30 \mathrm{~min}$ in darkness. Then cells were analyzed for determination of cell cycle phases using FACSCanto II cytometer (Becton-Dickinson).

\subsection{Statistical Analysis}

For parametric data one-way analysis of variance (ANOVA) followed by a Tukey test was applied. Results from five independent experiments were expressed as mean \pm standard deviation (SD) of mean for parametric data. Significance was considered when $p \leq 0.05$. Statistica 13.0 (StatSoft, Kraków, Poland) was used.

Acknowledgments: This work was financially supported by National Science Centre, Poland, under the research project number 2014/13/B/NZ7/02 352.

Author Contributions: Agata Jabłońska-Trypuć-corresponding author, wrote the paper, planned experiments; performed experiments; data analysis; Grzegorz Świderski-planned chemical experiments; performed chemical experiments; chemical data analysis; Rafał Krętowski-planned flow cytometry experiments; performed flow cytometry experiments; data analysis; Włodzimierz Lewandowski-planned experiments, data analysis.

Conflicts of Interest: The authors declare no conflict of interest.

Compliance with Ethical Standards: The manuscript does not contain clinical studies or patient data.

$\begin{array}{ll}\text { Abbreviations } & \\ \text { DOX } & \text { Doxorubicin } \\ \text { Cu-DOX } & \text { Complex of doxorubicin with } \mathrm{Cu} \text { (molar ratio 1:2) } \\ \text { Zn-DOX } & \text { Complex of doxorubicin with } \mathrm{Zn} \text { (molar ratio 1:2) } \\ \text { Co-DOX } & \text { Complex of doxorubicin with Co (molar ratio 1:2) } \\ \text { Ni-DOX } & \text { Complex of doxorubicin with Ni (molar ratio 1:2) } \\ \text { Fe-DOX } & \text { Complex of doxorubicin with Fe (molar ratio 1:3) } \\ \text { Mn-DOX } & \text { Complex of doxorubicin with Mn (molar ratio 1:2) } \\ \text { Mg-DOX } & \text { Complex of doxorubicin with Mg (molar ratio 1:2) }\end{array}$




\section{References}

1. Pilco-Ferreto, N.; Calaf, G.M. Influence of doxorubicin on apoptosis and oxidative stress in breast cancer cell lines. Int. J. Oncol. 2016, 49, 753-762. [CrossRef] [PubMed]

2. Turner, N.; Biganzoli, L.; Di, L.A. Continued value of adjuvant anthracyclines as treatment for early breast cancer. Lancet Oncol. 2015, 16, e362-e369. [CrossRef]

3. Szuławska, A.; Czyż, M. Molekularne mechanizmy działania antracyklin. Post. Hig. Med. Dośw. 2006, 60, 78-100.

4. Missailidis, S. Anticancer Therapeutics; John Wiley \& Sons: Chichester, UK, 2008; pp. 53-54.

5. Mitry, M.A.; Edwards, J.G. Doxorubicin induced heart failure: Phenotype and molecular mechanisms. IJC Heart Vasc. 2016, 10, 17-24. [CrossRef] [PubMed]

6. Komiyama, T.; Oki, T.; Inui, T. Interaction of new anthracycline antibiotics with DNA. Effects on nucleic acid synthesis and binding to DNA. Biochim. Biophys. Acta 1983, 740, 80-87. [CrossRef]

7. Gruber, B.M.; Anuszewska, E.L.; Bubko, I.; Goździk, A.; Fokt, I.; Priebe, W. Effect of structural modification at the 4, 3', and 2' positions of doxorubicin on topoisomerase II poisoning, apoptosis, and cytotoxicity in human melanoma cells. Arch. Immunol. Ther. Exp. 2007, 55, 193-198. [CrossRef] [PubMed]

8. Savatier, J.; Rharass, T.; Canal, C.; Gbankoto, A.; Vigo, J.; Salmon, J.M.; Ribou, A.C. Adriamycin dose and time effects on cell cycle, cell death, and reactive oxygen species generation in leukaemia cells. Leuk. Res. 2012, 36, 791-798. [CrossRef] [PubMed]

9. Feng, M.; Yang, Y.; He, P.; Fang, Y. Spectroscopic studies of copper(II) and iron(II) complexes of Adriamycin. Spectr. Acta A 2000, 56, 581-587. [CrossRef]

10. Sugioka, K.; Nakano, M. Mechanism of phospholipid peroxidation induced by ferric ion-ADP-adriamycincoordination complex. Bioch. Biophys. Acta 1982, 713, 333-343.

11. Greenaway, F.T.; Dabrowiak, J.C. The Binding of Copper Ions to Daunomycin and Adriamycin. J. Inorg. Biochem. 1982, 16, 91-107. [CrossRef]

12. Akman, S.A.; Doroshow, J.H.; Bruke, T.G.; Dizdaroglu, M. DNA base modifications induced in isolated human chromatin by NADH dehydrogenase- catalyzed reduction of doxorubicin. Biochemistry 1992, 31, 3500-3506. [CrossRef] [PubMed]

13. Beraldo, H.; Garnier-Suillerot, A.; Tosi, L.; Lavelle, F. Iron(III)-adriamycin and iron(III)-daunorubicin complexes: Physicochemical characteristics, interaction with DNA, and antitumor activity. Biochemistry 1985, 24, 284-289. [CrossRef] [PubMed]

14. Pereira, E.; Fiallo, M.; Garnier-Suillerot, A.; Kiss, T.; Kozłowski, H. Impact of aluminium ions on adriamycin-type ligands. J. Chem. Soc. 1993, 3, 455-459. [CrossRef]

15. Fiallo, M.M.L.; Garnier-Suillerot, A. Physicochemical studies of the iron(III)carminomycin complex and evidence of the lack of stimulated superoxide production by NADH dehydrogenase. Biochim. Biophys. Acta 1985, 840, 91-98. [CrossRef]

16. Fantine, E.; Garnier-Suillerot, A. Interaction of 5'-iminodaunorubicin with Fe(III) and with cardiolipin-containing vesicles. Biochim. Biophys. Acta 1986, 856, 130-136. [CrossRef]

17. Muindi, J.; Sinha, B.; Gianni, L.; Myers, C. Hydroxyl production and DNA damage induced by anthracycline-iron complex. FEBS Lett. 1984, 2, 226-230. [CrossRef]

18. Fiallo, M.M.L.; Garnier-Suillerot, A. Metal anthracycline complexes as a new class of anthracycline derivatives. Palladium(II)-adriamycin and palladium(II)-daunorubicin complexes: Physicochemical characteristics and antitumor activity. Biochemistry 1986, 25, 924-930. [CrossRef] [PubMed]

19. McLennan, I.J.; Lenkinski, R.E. The Binding of $\mathrm{Yb}(\mathrm{III})$ to Adriamycin-A H-1-NMR Relaxation Study. J. Am. Chem. Soc. 1984, 106, 6905-6909. [CrossRef]

20. Minotti, G.; Menna, P.; Salvatorelli, E.; Cairo, G.; Gianni, L. Anthracyclines: Molecular advances and pharmacologic developments in antitumor activity and cardiotoxicity. Pharm. Rev. 2004, 56, 185-229. [CrossRef] [PubMed]

21. Berlin, V.; Haseltine, W.A. Reduction of adriamycin to a semiquinone-free radical by NADPH cytochrome P-450 reductase produces DNA cleavage in a reaction mediated by molecular oxygen. J. Biol. Chem. 1981, 256, 4747-4756. [PubMed]

22. Jacobson, M.D.; Weil, M.; Raff, M.C. Programmed cell death in animal development. Cell 1997, 88, 347-354. [CrossRef] 
23. Wong, R.S. Apoptosis in cancer: From pathogenesis to treatment. J. Exp. Clin. Cancer Res. 2011, $30,87$. [CrossRef] [PubMed]

24. Lewandowski, W.; Kalinowska, M.; Lewandowska, H. The influence of metals on the electronic system of biologically important ligands. Spectroscopic study of benzoates, salicylates, nicotinates and isoorates. J. Inorg. Biochem. 2005, 99, 1407-1423. [CrossRef] [PubMed]

25. Koczoń, P.; Piekut, J.; Borawska, M.; Lewandowski, W. Vibrational structure and antimicrobial activity of selected isonicotinates, potassium picolinate and nicotinate. J. Mol. Struct. 2003, 651-653, 651-656. [CrossRef]

26. Kalinowska, M.; Piekut, J.; Bruss, A.; Follet, C.; Sienkiewicz-Gromiuk, J.; Świsłocka, R.; Rzączyńska, Z.; Lewandowski, W. Spectroscopic (FT-IR, FT-Raman, ${ }^{1} \mathrm{H}-,{ }^{13} \mathrm{C}-\mathrm{NMR}, \mathrm{UV} / \mathrm{VIS}$ ), thermogravimetric and antimicrobial studies of $\mathrm{Ca}(\mathrm{II}), \mathrm{Mn}(\mathrm{II}), \mathrm{Cu}(\mathrm{II}), \mathrm{Zn}(\mathrm{II} 0$ and $\mathrm{Cd}(\mathrm{II})$ complexes of ferulic acid. Spectrochim. Acta A 2014, 122, 631-638. [CrossRef] [PubMed]

27. Kowczyk-Sadowy, M.; Świsłocka, R.; Lewandowska, H.; Piekut, J.; Lewandowski, W. Spectroscopic (FT-IR, FT-Raman, ${ }^{1} \mathrm{H}$ - and ${ }^{13} \mathrm{C}$-NMR), theoretical and microbiological study of trans $o$-coumaric acid and alkali metal o-coumarates. Molecules 2015, 20, 3146-3169. [CrossRef] [PubMed]

28. Cheung, B.C.; Sun, T.H.; Leenhouts, J.M.; Cullis, P.R. Loading of doxorubicin into liposomes by forming $\mathrm{Mn}^{2+}$-drug complexes. Biochim. Biophys. Acta 1998, 1414, 205-216. [CrossRef]

29. Orvig, C.; Abrams, M.J. Medicinal inorganic chemistry: Introduction. Chem. Rev. 1999, 99, $2201-2204$. [CrossRef] [PubMed]

30. Chen, D.; Milacic, V.; Frezza, M.; Dou, Q.P. Metal complexes, their cellular targets and potential for cancer therapy. Curr. Pharm. Des. 2009, 15, 777-791. [CrossRef] [PubMed]

31. Haas, K.L.; Franz, K.J. Application of metal coordination chemistry to explore and manipulate cell biology. Chem. Rev. 2009, 109, 4921-4960. [CrossRef] [PubMed]

32. Fricker, S.P. Metal based drugs: From serendipity to design. Dalton Trans. 2007, 2007, 4903-4917. [CrossRef] [PubMed]

33. Meggers, E. Targeting proteins with metal complexes. Chem. Commun. 2009, 9, 1001-1010. [CrossRef] [PubMed]

34. Cohen, S.M. New approaches for medicinal applications of bioinorganic chemistry. Curr. Opin. Chem. Biol. 2007, 11, 115-120. [CrossRef] [PubMed]

35. Bouma, J.; Beijnen, J.H.; Bult, A.; Underberg, W.J.M. Anthracycline antitumour agents: A review of physicochemical, analytical and stability properties. Pharm. Weekbl. Sci. Ed. 1986, 8, 109-133. [CrossRef]

36. Chiu, G.N.C.; Abraham, S.A.; Ickenstein, L.M.; Ng, R.; Karlsson, G.; Edwards, K.; Wasan, E.K.; Bally, M.B. Encapsulation of doxorubicin into thermosensitive liposomes via complexation with the transition metal manganese. J. Cont. Release. 2005, 104, 271-288. [CrossRef] [PubMed]

37. Abraham, S.A.; Edwards, K.; Karlsson, G.; MacIntosh, S.; Mayer, L.D.; McKenzie, C.; Bally, M.B. Formation of transition metal-doxorubicin complexes inside liposomes. Biochim. Biophys. Acta 2002, 1565, 41-54. [CrossRef]

38. Fiallo, M.M.L.; Garnier-Suillerot, A. Copper(II)-anthracycline systems. Evidence of a dihydroxo-bridged dicopper(II) aclacinomycin complex. J. Inorg. Biochem. 1987, 31, 43-55. [CrossRef]

39. Lange, T.S.; Kim, K.K.; Singh, R.K.; Strongin, R.M.; McCourt, C.K.; Brard, L. Iron(III)-salophene: An organometallic compound with selective cytotoxic and anti-proliferative properties in platinum-resistant ovarian cancer cells. PLoS ONE 2008, 3, e2303. [CrossRef]

40. Ray, S.; Mohan, R.; Singh, J.K.; Samantaray, M.K.; Shaikh, M.M.; Panda, D.; Ghosh, P. Anticancer and antimicrobial metallopharmaceutical agents based on palladium, gold, and silver N-heterocyclic carbine complexes. J. Am. Chem. Soc. 2007, 129, 15042-15053. [CrossRef] [PubMed]

41. Sun, R.W.; Ma, D.L.; Wong, E.L.; Che, C.M. Some uses of transition metal complexes as anti-cancer and anti-HIV agents. Dalton Trans. 2007, 43, 4884-4892. [CrossRef]

42. Baile, M.B.; Kolhe, N.S.; Deotarse, P.P.; Jain, A.S.; Kulkarni, A.A. Metal Ion Complex-Potential Anticancer Drug-A Review. IJPRR 2015, 4, 59-66.

43. Milacic, V.; Chen, D.; Giovagnini, L.; Diez, A.; Fregona, D.; Dou, Q.P. Pyrrolidine dithiocarbamatezinc(II) and -copper(II) complexes induce apoptosis in tumor cells by inhibiting the proteasomal activity. Toxicol. Appl. Pharmacol. 2008, 231, 24-33. [CrossRef] [PubMed]

44. Sharifi, S.; Barar, J.; Hejazi, M.S.; Samadi, N. Doxorubicin Changes Bax /Bcl-xL Ratio, Caspase-8 and 9 in Breast Cancer Cells. Adv. Pharm. Bull. 2015, 5, 351-359. [CrossRef] [PubMed] 
45. Krętowski, R.; Borzym-Kluczyk, M.; Stypułkowska, A.; Brańska-Januszewska, J.; Ostrowska, H.; Cechowska-Pasko, M. Low glucose dependent decrease of apoptosis and induction of autophagy in breast cancer MCF-7 cells. Mol. Cell. Biochem. 2016, 417, 35-47. [CrossRef] [PubMed]

46. McGee, M.M.; Hyland, E.; Campiani, G.; Ramunno, A.; Nacci, V.; Zisterer, D.M. Caspase-3 is not essential for DNA fragmentation in MCF-7 cells during apoptosis induced by the pyrrolo-1,5-benzoxazepine, PBOX-6. FEBS Lett. 2002, 515, 66-70. [CrossRef]

47. Cuvillier, O.; Nava, V.E.; Murthy, S.K.; Edsall, L.C.; Levade, T.; Milstien, S.; Spiegel, S. Sphingosine generation, cytochrome $\mathrm{c}$ release, and activation of caspase-7 in doxorubicin-induced apoptosis of MCF7 breast adenocarcinoma cells. Cell Death Differ. 2001, 8, 162-171. [CrossRef] [PubMed]

48. Chitambar, C.R.; Wereley, J.P.; Matsuyama, S. Gallium-induced cell death in lymphoma: Role of transferrin receptor cycling, involvement of Bax and the mitochondria, and effects of proteasome inhibition. Mol. Cancer Ther. 2006, 5, 2834-2843. [CrossRef] [PubMed]

49. Green, M.A.; Welch, M.J. Gallium radiopharmaceutical chemistry. Int. J. Radiat. Appl. Instrum. B 1989, 16, 435-448. [CrossRef]

50. Yan, Y.; Hein, A.L.; Greer, P.M.; Wang, Z.; Kolb, R.H.; Batra, S.K.; Cowan, K.H. A novel function of HER2/Neu in the activation of G2/M checkpoint in response to $\gamma$-irradiation. Oncogene 2015, 34, 2215-2226. [CrossRef] [PubMed]

51. Tyagi, A.K.; Singh, R.P.; Agarwal, C.; Chan, D.C.; Agarwal, R. Silibinin strongly synergizes human prostate cancer DU145 cells to doxorubicin-induced growth inhibition, G2-M arrest, and apoptosis. Clin. Cancer Res. 2002, 8, 3512-3519. [PubMed]

52. Ling, Y.H.; el-Naggar, A.K.; Priebe, W.; Perez-Soler, R. Cell cycle dependent cytotoxicity, G2-M phase arrest, and disruption of p34cdc2/cyclin B1 activity induced by doxorubicin in synchronized p388 cells. Mol. Pharmacol. 1996, 49, 832-841. [PubMed]

53. Wadler, S.; Green, M.D.; Basch, R.; Muggia, F.M. Lethal and sublethal effects of the combination of doxorubicin and the bis-dioxopiperazine(+)-1,2-bis(3,5-diozopeperazinyl-1-yl) propane (ICRF 187) on murine sarcoma S180 in vitro. Biochem. Pharmacol. 1987, 9, 1495-1501. [CrossRef]

54. Das, G.; Nicastri, A.; Coluccio, M.L.; Gentile, F.; Candeloro, P.; Cojoc, G.; Liberale, C.; De Angelis, F.; Di Fabrizio, E. FT-IR, Raman, RRS measurements and DFT calculation for doxorubicin. Microscop. Res. Tech. 2010, 73, 991-995. [CrossRef] [PubMed]

55. Fornari, F.A.; Randolph, J.K.; Yalowich, J.C.; Ritke, M.K.; Gewirtz, D.A. Interference by doxorubicin with DNA unwinding in MCF-7 breast tumor cells. Mol. Pharmacol. 1994, 45, 649-656. [PubMed]

Sample Availability: Samples of compounds are not available from authors.

(C) 2017 by the authors. Licensee MDPI, Basel, Switzerland. This article is an open access article distributed under the terms and conditions of the Creative Commons Attribution (CC BY) license (http:/ / creativecommons.org/licenses/by/4.0/). 